\title{
PENERAPAN TEKNIK CERITA BERANTAI UNTUK MENINGKATKAN HISTORICAL IMAGINATION SISWA DALAM PEMBELAJARAN SEJARAH (Penelitian Tindakan Kelas di Kelas XI IPS 5 SMA Negeri 13 Bandung)
}

\author{
Iis Husnul Hotimah, Nana Supriatna, Yeni Kurniawati S
}

Universitas Pendidikan Indonesia

\begin{abstract}
This research is entitled "Surastri Karma Trimurti: The aim of this research is to increase student's Historical Imagination in Learning History. This research related to application of the Serial Story technique where this activity is a series of student's activity in learning history to increase student's historical imagination. The student's Historical imagination can be said was low, seen from student's evaluation result. They wasn't able to explore the content of the history. Some of them also can only memorize the facts that related to the content. The students wasn't able to imagining period of history chronogically, also wasn't able to imagining how an even could happens and how the atmosphere in the past was like when an historical even happened. The method of this research is Classroom Action Research with Elliot's desain. This desain has several act steps such as Recconaisance, and then a plans, observe and reflect. These steps are repeated for several cycles until the learning procces is success and compatible with the aims of this research. Data collecting technique that used in this research were observe and interview and data collecting tools were interview guidelines, field note, and observation guidelines. The indicators of this research are pupils can feel themselves in the event of history by expressing their opinions about the event. Second, revealed the possibilities that will occur if the pupils become a figure or if they were in the event. Third, describe by writing, the situation or condition also the figures emotion, how they feel right in that event. Fourth, imagining the story using figurative language and the last is when they are telling the story, they can express their feeling by the face expression and also body gesture according to the story. Based on this research the aim of this research was reached with the increasing point in every indicator.
\end{abstract}

Key Words: Historical Imagination, Learning History, The Series Story Technique.

\section{ABSTRAK}

Penelitian ini bertujuan untuk meningkatkan Historical Imagination siswa dalam Pembelajaran Sejarah. Penelitian ini berkaitan dengan penerapan serangkaian kegiatan siswa dalam Pembelajaran Sejarah untuk meningkatkan imajinasi kesejarahan siswa. Imajinasi kesejarahan siswa rendah terlihat dari hasil evaluasi siswa yang kurang dapat mengeksplorasi materi lebih jauh. Sebagian dari mereka juga hanya dapat menghafal fakta-fakta yang berkaitan dengan materi. Siswa kurang mampu untuk membayangkan (imagining) kurun waktu sejarah secara kronologis, kurang mampu membayangkan bagaimana (how) suatu peristiwa bisa terjadi dan bagaimana gambaran suasana pada saat peristiwa sejarah berlangsung (what the past was like). Untuk itu peneliti mencoba melakukan penelitian dengan menggunakan metode Penelitian Tindakan Kelas dengan desain Elliot. Desain model ini memiliki beberapa tahapan diantaranya memeriksa di lapangan (Recconaisance), kemudian perencanaan tindakan, pelaksanaan tindakan, pengamatan dan refleksi kemudian dilanjutkan dengan merevisi kekurangan yang ada dan kemudian terus berulang sebanyak beberapa siklus sampai proses pembelajaran berhasil dengan tujuan yang diharapkan peneliti. Teknik pengumpulan data yang digunakan ialah wawancara dan observasi sementara alat pengumpulan data yang digunakan ialah lembar observasi, catatan lapangan dan lembar wawancara. Indikator-indikator dalam penelitian ini terdiri dari merasakan dirinya berada dalam peristiwa sejarah dengan mengungkapkan pendapatnya tentang suatu peristiwa, mengungkapkan kemungkinan-kemungkinan yang terjadi apabila siswa menjadi tokoh atau berada dalam peristiwa sejarah, mendeskripsikan secara tertulis situasi kondisi atau emosi tokoh dalam suatu cerita, dapat mengimajikan cerita menggunakan bahasa kiasan dan yang terakhir ialah ketika bercerita mimik muka sesuai dengan emosi, karakter, atau suasana suatu peristiwa. Berdasarkan pada hasil penelitian yang diperoleh dengan menggunakan teknik ini, penerapan teknik cerita berantai dapat meningkatkan imajinasi kesejarahan siswa dalam Pembelajaran Sejarah di kelas XI IPS 5 SMA Negeri 13 Bandung dengan peningkatan indikator-indikator tersebut disetiap siklusnya.

Kata Kunci : Historical Imagination, Pembelajaran sejarah, Teknik Cerita Berantai tahun 1948.

Author correspondence

Email: Husnuliis12@gmail.com

Available online at http: // http://ejournal.upi.edu/index.php/factum 


\section{PENDAHULUAN}

Dalam upaya mengembangakan manusia ke arah sumber daya manusia yang optimal dan lebih baik, diharapkan potensi-potensi manusia suatu bangsa harus berkembang. Hal ini dapat dilakukan dengan melalui berbagai proses pendidikan, baik di rumah, sekolah atau di masyarakat. Pendidikan sebagaimana yang diatur dalam UU Nomor 20 Tahun 2003 tentang Sistem Pendidikan Nasional dinyatakan sebagai usaha sadar dan terencana untuk mewujudkan suasana belajar dan proses pembelajaran agar peserta didik secara aktif mengembangkan potensi dirinya untuk memiliki kekuatan spiritual keagamaan, pengendalian diri, kepribadian, kecerdasan, akhlak mulia, sertaketerampilanyang diperlukan dirinya, masyarakat, bangsa dan negara. Dengan melihat ketentuan yang ada di dalam peraturan perundang-undangan tersebut maka upaya peningkatan pendidikan terus dilakukan pemerintah, salah satunya adalah di tingkat menengah atas. Upaya peningkatan pendidikan di sekolah menengah atas juga merupakan salah satu aspek di dalam pembangunan pendidikan di Indonesia dewasa ini selain di sekolah menengah dasar dan sekolah menengah pertama. Salah satu usaha pemecahan masalah guna peningkatan kualitas pendidikan adalah dengan memperbaiki sistem pembelajaran oleh guru yang antara lain tidak lagi menggunakan sistem pembelajaran yang konvensional melainkan menggunakan pendekatanpendekatan baru dalam pembelajaran. pendekatan konvensioinal dianggap sudah tidak relevan lagi dimasa sekarang ini yang penuh dengan teknologi. Kita dituntut untuk memanfaatkan kemajuan jaman demi tercapainya tujuan pendidikan dan menghasilkan siswa-siswi yang diharapkan. Pembelajaran konvensional biasanya diisi dengan ceramah sementara siswa dipaksa menerima dan menghafal. Jarang sekali guru melaksanakan kegiatan pembelajaran dengan mengutamakan kegiatan penemuan. Pembelajaran seperti itu sebaiknya di ubah dan digantikan dengan pilihan strategi pembelajaran yang lebih berpihak dan memberdayakan siswa atau Student Center Approach.

Masalah utama dalam pembelajaran sejarah dikelas ialah kurangnya guru menggunakan pendekatan pembelajaran yang akan meningkatkan kemampuan siswa dlaam belajar. Siswa dituntut untuk mengerjakan LKS dan merangkum pembahasan dalam LKS. Pembelajaran Sejarah jika dikembangkan dengan baik maka akan sangat berguna karena terdapat nilai-nilai yang bermanfaat bagi kehidupan siswa. Metode ceramah dalam proses belajar mengajar terkesan sangat kaku, kurang fleksibel, kurang demokratis, dan guru cenderung lebih dominan (Teacher Center Approach). Guru juga terkadang hanya meminta siswa untuk membaca sendiri materi di buku paket dan LKS. Sementara pembelajaran sejarah menuntut siswa untuk memahami secara lebih mendalam tentang suatu peristiwa. Siswa harus mengeksplore lebih jauh sehingga siswa akan menemukan nilai apa yang akan mereka resapi dan menimbulkan rasa empati siswa terhadap peristiwa. Pembelajaran sejarah juga hendaknya menjadi wahana rekreasi siswa ke masa lalu yang akan membuat pemahaman siswa menjadi lebih dalam.

Salah satu alternatifnya dalam membuat pembelajaran sejarah lebih bermakan adalah denganmenggunakanTeknikCeritaBerantai. Dalam pembelajaran menggunakan teknik 
ini melibatkan siswa dalam keseluruhan proses pembelajaran sehingga siswa akan aktifdalam pembelajaran. siswa akan melalui berbagai proses pembelajaran untuk lebih mengembangkan pemahamannya dan pada akhirnya siswa akan membuat sendiri cerita tentang sejarah dan mempresentasikannya menggunakan teknik ini. Oleh karena itu teknik ini dianggap lebih efektif dan efesien dalam menggantikan pendekatan konvensional. Namun dalam kenyataannya masih banyak guru yang belum dapat melaksanakan berbagai pendekatan baru dalam pembelajaran termasuk melaksanakan pendekatan pembelajaran yang didasarkan pada Teknik Cerita Berantai. Jarangnya guru menggunakan teknik ini dalam pembelajaran disebabkan oleh keterbatasan kemampuan guru dalam memahami dan mengaplikasikannya. Dalam penelitian yang dibuat menjadi artikel ini memiliki tujuan untuk mengungkapkan dan menggambarkan hal-hal berikut:

1. Mendeskripsikan perencanaan pembelajaran dengan menggunakan teknik cerita berantai untuk meningkatkan kemampuan berimajinasi dalam pembelajaran sejarah di kelas XI IPS 5 SMAN 13 Bandung.

2. Menjabarkan tahapan-tahapan pelaksanaan teknik cerita berantai untuk meningkatkan kemampuan berimajinasi siswa dalam pembelajaran sejarah di kelas XI IPS 5 SMAN 13 Bandung.

3. Mendeskripsikan hasil pelaksanaan penggunaan teknik cerita berantai untuk meningkatkan kemampuan berimajinasi siswa dalam pembelajaran sejarah di kelas XI IPS 5 SMAN 13 Bandung.
Sementara manfaat dari penelitian ini ialah:

1) Bagi Sekolah. Dengan adanya penelitian ini, diharapkan dapat menumbuhkan atau meningkatkan kemampuan berimajinasi siswa dalam pembelajaran sejarah di SMAN 13 Bandung dan ketercapaian standar kompetensi sesuai dengan kurikulum sejarah sehingga dapat meningkatkan kualitas pembelajaran sejarah di SMAN 13 Bandung.

2) Bagi Guru. Dengan adanya penelitian ini diharapkan guru dapat memperbaiki memperbaiki permasalahan yang dihadapi khususnya dalam pembelajaran sejarah sehingga keterampilan guru dalam mengajar juga diharapkan dapat meningkat. Selain itu juga dapat menambah referensi guru dalam menggunakan metode dalam upaya mengembangkan pembelajaran di sekolah.

3) Bagi Siswa. Dengan adanya penelitian mengenai penerapan teknik permainan cerita berantai ini diharapkan dapat menumbuhkan atau meningkatkan kemampuan berimajinasi siswa khususnya pada pembelajaran sejarah dan melalui teknik ini, diharapkan juga dapat membantu siswa dalam merekonstruksi masa lalu sehingga pemahaman siswa terhadap pembelajaran sejarah mdapat mengalami peningkatan.

4) Bagi Peneliti. Dengan adanya penelitian tentang penerapan teknik permainan cerita berantai untuk meningkatkan kemampuan berimajinasi siswa ini, peneliti dapat mendapatkan pengalaman langsung dilapangan mengenai berbagai metode 
pembelajaran serta penilaiannya yang tentu saja menambah wawasan peneliti sebagai bekal untuk menjalankan tugas sebagai guru sejarah.

\section{METODE PENELITIAN}

Dalam suatu penelitian, metode penelitian sangat perlu untuk digunakan untuk membantu peneliti dalam memecahkan masalah yang sedang diteliti. Seperti halnya yang dikemukakan oleh Sugiyono (2012, hal. 2) yang mengemukakan bahwa metode penelitian pada dasarnya merupakan cara ilmiah untuk mendapatkan data dengan tujuan dan kegunaan tertentu. Metode penelitian yang digunakan dalam penelitian ini ialah metode Penelitian Tindakan Kelas (PTK). Metode ini digunakan oleh peneliti dengan alasan ialah bahwa peneliti ingin memperbaiki masalah-masalah yang terdapat dalam siswa dikelas dalam suatu pembelajaran. sesuai dengan pengertiannya, metode ini digunakan untuk memecahkan maslaah yang terjadi di kelas dalam dunia pendidikan sehingga metode ini sesuai dengan tujuan peneliti. Dengan memperbaiki permasalahn dikelas, diharapkan juga penelitian dapat meningkatkan mutu pendidikan.

Menurut hemat penulis, selain alasanalasan diatas, penelitian tindakan kelasjuga dapat memicu tumbuhnya budaya meneliti pada pengajar sehingga dapat menambah wawasan para pengajar. Itulah mengapa penulis memilih metode penelitian tindakan kelas ini agar penulis juga dapat menambah wawasan penulis melalui metode ini. Sementara desain penelitian dalam penelitian ini ialah desain penelitian model desain Elliot (dalam Wiriaatmadja, 2006, Hlm. 64) yang tahapannya terdiri dari Identifikasi masalah, memeriksa di lapangan (Recconaisance), kemudian perencanaan tindakan, pelaksanaan tindakan, pengamatan dan refleksi kemudian dilanjutkan dengan merevisi kekurangan yang ada dan kemudian terus berulang sebanyak beberapa siklus sampai proses pembelajaran berhasil dengan tujuan yang diharapkan peneliti. Penelitian ini menggunakan desain Elliot karena proses yang direncanakan peneliti selaras dengan tahapan-tahapan desain ini. Tahapan-tahapan tersebut dijelaskan lebih lanjut dibawah ini:

1. Identifikasi Masalah

Identifikasi masalah atau kegiatan observasi awal dilakukan untuk mengetahui permasalahan-permasalahan yang timbul dalam penelitian. Dalam kegiatan ini peneliti melakukan identifikasi masalah di kelas XI IPS 5 SMA Negeri 13 Bandung yang tentu saja peneliti sudah melakukan kerjasama dengan mitra guru kelas tersebut.

2. Memeriksa Lapangan (Reconnaisance)

Kegiatan ini merupakan kegiatan memahami situasi yang muncul berdasarkan identifikasi masalah hasil pengamatan dilapangan yang nantinya dapat dijadikan fokus penelitian dan dicari solusi untuk menyelesaikan masalah tersebut. Tahapan ini dilaksanakan oleh peneliti yang termasuk ke dalam tahapan pra-penelitian. Kegiatan ini dilaksanakan sebelum peneliti melaksanakan Program Pelatihan Lapangan (PPL) di SMA yang sama. Peneliti melakukan kegiatan ini di SMA Negeri 13 Bandung.

3. Perencanaan Tindakan

Pada tahapan perencanaan ini peneliti melakukan pengamatan terlebih dahulu terhadap kondisi siswa yang 
berdasarkan kepada kegiatan sebelumnya yaitu pra-penelitian yang dilakukan agar dapat menentukan strategi apa yang akan dilakukan untuk melakukan perbaikan terhadap pembelajaran sejarah. perencanaan ini juga dilakukan peneliti untuk menentukan topic atau tema pembelajaran yang sesuai dengan penerapan teknik cerita berantai untuk meningkatkan imajinasi kesejarahan siswa di kelas XI IPS 5 SMAN 13 Bandung serta menentukan waktu dan format observasi yang digunakan kemudian instrumentinstrumen penelitianlainnya. Padatahapan ini peneliti melakukan diskusi dengan guru mitra dan dosen pembimbing tentang Rancangan Pelaksanaan Pembelajaran, alat evaluasi hingga Kompetensi dasar yang mana yang cocok untuk materi tindakan.

\section{Tahap tindakan (Acting)}

Ini merupakan tahap penerapan dari berbagai rencana yang sudah dirancang pada tahap sebelumnya. Pada tahap dalam setiap tindakan memiliki cara yang berbeda-beda. Pada tindakan pertama sampai kedua peneliti hanya menjelaskan materi saja dan media lainnya untuk memancing imajinasi siswa. Sementara pada tindakan 3-6, siswa bekerja secara berkelompok. Pada tahapan tindakan ini, peneliti menggunakan berbagai media untuk membantu pembelajaran seperti video documenter, audio visual serta gambar dan media lainnya.

\section{Tahap Pengamatan (Observation)}

Tahap ini dilaksanakan bersamaan dengan tahap tindakan. Sambil melakukan tindakan, peneliti sekaligus mengamati. Selain itu peneliti juga melakukan analisis berdasarkan pengamatan pada pelaksanaan tindakan. Proses pengamatan harus fleksibel dan terbuka untuk dapat mencatat gejala yang muncul baik yang diharapkan ataupun yang tidak. Pada tahap ini peneliti dibantu 2-3 orang rekan yang membantu menulis catatan lapangan, mendokumentasikan kegiatan dan mencatat di lembar observasi. Pada tahapan ini, yang dilakukan peneliti ialah:

a. Mengamati kelas yang diteliti.

b. Mengamati kesesuaian penggunaan teknik cerita berantai dengan pokok bahasan yang sedang dibahas.

c. Mengamati kemampuan siswa berdiskusi dan mengerjakan soal.

\section{Refleksi (reflect)}

Refleksi menurut Sukidin (2010, hlm. 112) adalah kegiatan mengulas secara kritis (reflective) tentang perubahan yang terjadi, baik pada siswa, suasana kelas, maupun guru. Sedangkan menurut Arikunto (2010, hlm. 40) refleksi ialah kegiatan untuk mengemukakan kembali apa yang telah terjadi, arti dari refleksi sebetulnya ialah lebih tepat jika digunakan ketika guru selesai melakukan tindakan kemudian dengan kolaborator bersamasama mendiskusikan implementasi rancangan tindakan. Dari pengertianpengertian diatas dapat disimpulkan bahwa kegiatan refleksi merupakan kegiatan pengkajian ulang terhadap data yang telah didapat pada saat observasi. Pada kegiatan ini, peneliti melakukan kegiatan diskusi dengan kolaborator maupun mitra dan siswa setelah tindakan dan merefleksikan hasil diskusi balikan untuk siklus selanjutnya. Pada tahapan refleksi ini, peneliti melihat kendalakendala yang ada di lapangan pada saat tindakan dan mencoba mencari solusi agar tidak terjadi lagi di tindakan berikutnya. 


\section{HASIL PENELITIAN DAN PEMBAHASAN}

Menurut Priadhita (2013, hlm. 16) pembelajaran sejarah adalah proses interaksi antara siswa dengan lingkungannya, sehingga terjadi perubahan tingkah laku akibat dari interaksinya dengan mempelajari sejarah. Pembelajaran sejarah bukan hanya sekedar proses menghafal fakta-fakta dan peristiwa namun pembelajaran sejarah juga mengharuskan siswa untuk berfikir secara kronologis, memiliki pengetahuan masa lampau, dan juga dapat memahami perkembangan sosial budaya masyarakat dalam rangka menemukan jati diri bangsa. Menurut Jumono (2012, hlm. 2) fungsi sejarah pada hakekatnya adalah untuk meningkatkan pengertian atau pemahaman yang mendalam dan lebih baik tentang masa lampau dan juga masa sekarang dalam inter relasinya dengan masa mendatang. Sedangkan kegunaan atau manfaat sejarah ada empat yakni yang bersifat edukatif yakni bahwa pelajaran sejarah membawa kebijaksanaan dan kearifan; kedua, yang bersifat inspiratif artinya memberi ilham; ketiga, bersifat instruktif, yaitu membantu kegiatan menyampaikan pengetahuan atau ketrampilan, dan keempat, bersifat rekreatif, yakni memberikan kesenangan estetis berupa kisah-kisah nyata yang di alami manusia. Sebagai suatu pembelajaran, Sejarah memiliki tujuantujuan yang tentu saja diharapkan dapat dicapai oleh peserta didik. Menurut Ismaun (2001, hlm. 106), tujuan umum dan ideal pendidikan dan pengajaran sejarah adalah agar peserta didik mampu: 1) memahami sejarah, 2) memiliki kesadaran sejarah, dan 3) memiliki wawasan sejarah yang bermuara pada kearifan sejarah..
Searah dengan pendapat Kartodirdjo (dalam Agung, 2012, hlm. 413) bahwa dalam rangka pembangunan bangsa, pengajaran Sejarah tidak sematamata berfungsi untuk memberikan pengetahuan Sejarah sebagai kumpulan informasi fakta Sejarah tetapi juga bertujuan menyadarkan peserta didik atau membangkitkan kesadaran Sejarahnya. Sehingga tidak dapat dipungkiri bahwa pendidikan sejarah mempunyai fungsi yang sangat penting dalam membentuk kepribadian bangsa, kualitas manusia dan masyarakat Indonesia umumnya. Untuk membangkitkan kesadaran sejarah siswa, dibutuhkan imajinasi kesejarahan dalam diri siswa untuk melihat masa lalu. Dalam pembelajaran sejarah, imajinasi sangat diperlukan untuk membayangkan masa lalu yang dapat membantu peserta didik memahami suatu peristiwa.

Menurut Ma`mur (2008), terdapat standar dalam pembelajaran sejarah yang harus dicapai siswa salah satunya ialah Historical Thinking Skills, yaitu kemampuan berpikir kesejarahan yang memungkinkan anak/siswa untuk membedakan masa lalu, masa sekarang, dan masa yang akan datang, membangun pertanyaan, mencari dan mengevaluasi bukti-bukti, membandingkan dan menganalisis kisah-kisah sejarah, ilustrasi-ilustrasi, dan catatan-catatan dari masa lalu, menginterpretasikan catatancatatan sejarah dan mengkonstruksinarsi sejarah menurut versi masing-masing siswa atau anak. Dalam merekonstruksi masa lalu siswa membutuhkan imajinasi dalam pikirannya sehingga siswa dapat membayangkan peristiwa sejarah yang terjadi. Seperti yang dikatakan oleh Collingwood (dalam Soffer, 1996) bahwa: 
"historical imagination as an innate or a priori part of thinking that allows students of history to reconstruct the past.' Whether stored in the furniture of the mind, learned through practice, or inherited as genetic inclinations, imagination is indispensable to the historian's craft". (hlm. 1).

Kuntowijoyo (1995), menyatakan bahwa setidaknya ada tiga hal penting bahwa seorang sejarawan haruslah dapat membayangkan yaitu apa yang sebelumnya terjadi, apa yang sedang terjadi, dan apa yang terjadi sesudah itu. mengenai kesadaran sejarah, lebih lanjut Jumono (2012, hlm. 1) mengatakan bahwa kesadaran sejarah akan mampu membimbing manusia kepada pengertian mengenai diri sendiri sebagai bangsa memahami betapa pentingnya kesadaran sejarah, maka pengembangan pendidikan sejarah merupakan tuntutan untuk melahirkangenerasibijaksanayangmampu menyelesaikan permasalahan bangsa dengan bijaksana. Sebagai suatu ilmu, pembelajaran sejarah tentunya memiliki fungsi, manfaat dan tujuan seperti halnya ilmu-ilmu lainnya. Melihat fungsi-fungsi diatas seorang tenaga pendidik ternyata memiliki tanggung jawab yang besar dalam rangka mewujudkan pembelajaran sejarah yang bermakna serta dapat memunculkan rasa empati kesejarahan siswa. Untuk itu diperlukan metode dan teknik pembelajaran yang dapat membantu tujuan-tujuan pembelajaran. dalam penelitian ini, peneliti menggunakan teknik permainan cerita berantai untuk meningkatkan Historical Imagination siswa dalam pembelajaran sejarah. Teknik permainan cerita berantai merupakan teknik permainan yang pada umumnya digunakan dalam pembelajaran bahasa yang memfokuskan pada keterampilan berbicara. Namun teknik ini dapat juga diterapkan dalam pembelajaran sejarah karena melalui bercerita diharapkan imajinasi sejarah siswa dapat muncul. Tarigan (1990) berpendapat bahwa teknik cerita berantai adalah salah satu teknik dalam pengajaran berbicara yang menceritakan suatu cerita kepada siswa pertama, kemudian siswa pertama menceritakan kepada siswa kedua, dan seterusnya kemudian cerita tersebut diceritakan kembali lagi kepada siswa yang pertama. Pemilihan teknik cerita berantai ini, karena teknik ini mampu mengajak siswa untuk bercerita dan melalui cerita inilah imajinasi siswa dikembangkan.

Dari hasil penelitian yang tersaji dalam dua siklus dan setiap siklus memiliki masing-masing enam tindakan, dapat dikatakan bahwa teknik ini mampu memunculkan imajinasi siswa dalam pembelajaran sejarah terlihat dari meningkatnya indikator-indikator imajinasi kesejarahan atau Historical Imagination siswa.

Tabel Kenaikan Indikator Historical Imagination Siswa

\begin{tabular}{|l|l|l|l|}
\hline No Indikator & Indikator & Siklus 1 & siklus II \\
\hline 1 & $\begin{array}{l}\text { Merasakan dirinya berada dalam peristiwa } \\
\text { sejarah dengan mengungkapkan pendapatnya } \\
\text { tentang suatu peristiwa }\end{array}$ & $24,44 \%$ & $28,89 \%$ \\
\hline 2 & $\begin{array}{l}\text { Mengungkapkan kemungkinan-kemungkinan } \\
\text { yang terjadi apabila siswa menjadi tokoh atau } \\
\text { berada dalam peristiwa sejarah }\end{array}$ & $26,67 \%$ \\
\hline
\end{tabular}




\begin{tabular}{|l|l|l|l|}
\hline 3 & $\begin{array}{l}\text { Mendeskripsikan secara tertulis situasi, kondisi } \\
\text { atau emosi tokoh dalam suatu cerita }\end{array}$ & 27,78\% & 30,56 \\
\hline 4 & $\begin{array}{l}\text { Dapat mengimajikan cerita menggunakan } \\
\text { bahasa kiasan }\end{array}$ & $22,22 \%$ & $\mathbf{2 7 , 7 8 \%}$ \\
\hline 5 & $\begin{array}{l}\text { Ketika bercerita Mimik muka sesuai dengan } \\
\text { emosi, karakter, atau suasana suatu peristiwa }\end{array}$ & $30,56 \%$ & $33,33 \%$ \\
\hline \multicolumn{2}{|l|}{ Rata-rata keseluruhan indikator siklus I dan 2 } & $25,444 \%$ & $\mathbf{2 9 , 4 4 6 \%}$ \\
\hline
\end{tabular}

Indikator pertama pada tindakan pertama dalam siklus 1 mendapatkan skor 24,44\% yang artinya angka ini menunjukan bahwa rasa empati siswa atau mereka ikut merasakan dirinya berada dalam suatu peristiwa sejarah sudah terlihat dari mimic muka siswa yang serius mendengarkan penjelasan guru. Contohnya ketika guru menjelaskan bagaimana penderitaan para romusha atau kekejaman para tentara Jepang banyak siswa yang mengernyitkan muka, namun siswa belum mampu memperlihatkan responnya terhadap apa yang mereka rasakan melalui pertanyaan atau pendapat. Jika sebelumnya skor yang diraih masih sangat rendah yaitu 22, pada tindakan dalam siklus kedua ini terdapat kenaikan menjadi 26 dengan presentase 28,89\%. Angka ini menunjukan bahwa siswa sudah menunjukan reaksinya terhadap materi dan rasa ingin tahunya yang lebih terhadap materi dengan mengajukan pertanyaan dan pendapat. Contohnya pada saat peneliti menjelaskan bagaimana kecewanya Hatta bahwa ternyata 1,5 juta orang penduduk Indonesia yang dilaporkan oleh golongan muda akan datang mendengarkan proklamasi belum ada sama sekali, mereka menunjukan mimik muka yang serius memperhatikan peneliti serta sudah berani mengutarakan pendapatnya tentang peristiwa tersebut.
Mereka menunjukan raut muka yang sedih ketika peneliti menjelaskan bagianbagian sejarah yang membuat prihatin dan mereka mampu mengutarakan apa yang mereka rasakan.

Sementara skor yang di dapat pada indikator nomor 2 ialah 20 dengan presentase 22,22\% yang berarti angka ini menunjukan bahwa banyak siswa yang terlihat memiliki ide untuk berpendapat namun hanya beberapa siswa saja yang mampu memenuhi indikator ini yaitu dapat menempatkan dirinya sebagai tokoh sejarah dan membuat suatu alternative cerita sejarah yang berisi banyak kemungkinan yang akan terjadi. Setelah dilakukan tindakan lagi pada siklus kedua indikator ini juga mengalami peningkatan skornya ialah 24 dengan rata-rata 26,67\%. Hal ini menunjukan bahwa banyak siswa yang memperhatikan dan menunjukan reaksinya dengan bertanya dan berpendapat. Contohnya ketika peneliti menjelaskan bagaimana kecewanya Hatta bahwa ternyata 1,5 juta orang penduduk Indonesia yang dilaporkan oleh golongan muda akan datang mendengarkan proklamasi belum ada sama sekali, mereka menunjukan mimik muka yang serius yang menandakan siswa belum pernah mendengar cerita ini sebelumnya dan pada akhirnya banyak siswa yang dapat 
mengungkapkan pendapatnya mengapa kedua golongan yaitu golongan tua dan muda memiliki pendapat masing-masing. Siswa juga menentuka ingin menjadi siapa mereka jika berada dalam suasana tersebut dan apa yang akan mereka lakukan.

Pada saat siswa membuat cerita, indikator nomor tiga ini diharapkan muncul dalam cerita siswa, namun pada siklus 1, dalam mendeskripsikan situasi, kondisi atau emosi tokoh dalam cerita tertulis beberapa kelompok masih belum mampu mendeskripsikan secara rinci indikator tersebut. Mereka masih berada pada taraf mengutarakan fakta-fakta baku yang mereka dapatkan dari sumber bacaan. Pada siklus kedua, indikator ini mengalami kenaikan walaupun tidak begitu signifikan Cerita siswa masih terkesan kaku karena tidak disertai kata-kata kiasan yang akan lebih menggambarkan suasana dan dapat menghidupkan cerita sejarah tersebut. Sementara kelompok lainnya sudah dapat mencapai indikator ini. Mereka menggambarkan dan menghidupkan kembali suatu cerita dengan jelas sehingga ketika mempresentasikan hasilnya pendengar bisa terbawa ke dalam cerita sejarah. Sementara indikator nomor empat beberapa kelompok siswa sudah bisa mengolah fakta menjadi judul suatu cerita yang menarik serta sudah dapat menggambarkan suatu peristiwa sejarah melalui imajinasinya dan menuliskannya kedalam suatu cerita sejarah. Beberapa kelompok siswa juga sudah dapat menggambarkan bagaimana reaksi suatu tokoh lewat bahasa kiasan dengan baik namun masih banyakjuga siswayang belum mencapai indikator-indikator tersebut sehingga cerita terkesan monoton. Pada siklus kedua indikator ini juga mengalami kenaikan terlihat dari meningkatnya skor yang diraih. Ini menandakan bawa masih belum semua kelompok mampu memunculkan indikator ini. Mereka belum menggambarkan suatu peristiwa sejarah dengan bahasa yang dapat membawa pembaca atau pendengar masuk ke dalam suatu peristiwa dikarenakan teks nya yang masih terkesan monoton, kurang kaya akan bahasa kiasan dan pengandaian. Namun secara keseluruhan terdapat peningkatan dari sebelumnya.

Pada indikator terakhir, sebagian siswa sudah mamapu menyelaraskan antara mimic atau ekspresi muka dengan gerakan atau gesture tubuh ketika bercerita, namun sebagian siswa hanya dapat memunculkan salah satu diantaranya. Misalkan gesture tubuhnya bagus tetapi mimik muka tidak muncul atau sebaliknya. Pada siklus kedua mereka sudah mampu menggambarkan dengan jelas situasi kondisi peristiwa yang mereka ceritakan dengan mimik muka yang sesuai. Mereka dapat menyelaraskan gerak tubuh saat bercerita dengan mimic dan ekspresi muka saat bercerita. Contohnya ketika kelompok 3 bercerita tentang judul "akhirnya kita merdeka" pada saat bagian menceritakan rakyat Indonesia bersorak “merdeka!! Merdeka!!" itu diucapkan sambil mengepalkan tangan dan ekspresi yang bersemangat. Namun tidak semua kelompok dapat mencapai indikator ketiga, terdapat kelompok yang belum dapat menyelaraskan indikator itu dengan baik. Suara mereka kurang bersemangat namun gesture tubuh dan ekspresi sudah tepat.

\section{SIMPULAN}

Berdasarkan hasil penelitian tindakan kelas yang telah dilaksanakan di kelas XI IPS 5 SMA Negeri 13 Bandung, maka 
dapat ditarik kesimpulan bahwa Terdapat peningkatan imajinasi kesejarahan siswa dalam pembelajaran sejarah melalui teknik cerita berantai serta Terjadi beberapa perubahan pada siswa yang dapat diamati secara langsung yaitu: 1). Mulai dapat menunjukan reaksi ketika pembelajaran berlangsung yaitu dengan mengajukan pendpat atau pertanyaan, 2). Tidak lagi diam pada saat pembelajaran dan sibuk dengan aktifitas masing-masing, melainkan serius memperhatikan dan aktif berpendapat, 3). Terbiasa untuk berfikir lebih dalam dalam pembelajaran sejarah, 4). Mampu untuk menempatkan dirinya menjadi pelaku sejarah dan mampu membuat suatu cerita sejarah berdasarkan beberapa sumber yang relevan.

\section{DAFTAR PUSTAKA}

Agung, L.S (2012). Pengembangan model pembelajaran sejarah SMA berbasis pendidikan arakter di Solo Raya. Jurnal Pendidikan dan Kebudayaan. 4 (18). Hal 413.

Arikunto, S. (2006). Prosedur penelitian suatu pendekatan. Jakarta: RINEKA CIPTA.

Ismaun. (2001). Paradigma pendidikan sejarah yang terarah dan bermakna. Jurnal: Historia. 2(4). Hlm. 106.

Jumono, J. (2012). Pengelolaan pembelajaran sejarah berbasis multimedia di SMA Negeri 1 Boja Kendal. (Tesis). Surakarta: Universitas Muhammadiyah Surakarta.

Kelembagaan Riset Dikti. (2003). Undangundang Republik Indonesia tentang sistem pendidikan nasional. [Online]. Diakses dari http://kelembagaan. ristekdikti.go.id/wp-content/ uploads/2016/o8/UU_no_2o_ th_2003.pdf
Kuntowijoyo. Pengantar ilmu sejarah. Yogyakarta: Yayasan Bentang Budaya, 1995.

Ma'mur, T. (2008). Upaya Meningkatkan Kualitas Pembelajaran Sejarah Melalui Historical Thinking. Bandung : Jurusan Pendidikan Sejarah FPIPS UPI

Priadhita, A.R. (2013). Penerapan teknik Numbered Head Together pada siswa kelas X1 SMA PGRI 1 Temanggung. (Skripsi). Yogyakarta: Universitas Negeri Yogyakarta.

Sugiyono. (2008). Metodologi penelitian pendidikan pendekatan kualitataif, Kuantitatif. Bandung: Alfabeta.

Soffer, R.N. (1996). The conservative historical imagination in the twentieth century. Albion. Hlm. 1.

Sukidin, dkk. (2010). Manajemen penelitian tindakan kelas. Insane cendikia.

Tarigan, D. \& Tarigan, H.G. (1990). Teknik Pengajaran Keterampilan Berbahasa. Bandung: Angkasa.

Wiraatmadja, R. (2006). Metode penelitian kelas untuk meningkatkan kinerja guru dan dosen. Bandung: PT. Remaja Rosda Karya.

\section{INDEKS AUTHOR}

Jumono, J. (2012). Pengelolaan pembelajaran sejarah berbasis multimedia di SMA Negeri 1 Boja Kendal. (Tesis). Surakarta: Universitas Muhammadiyah Surakarta.

Wiraatmadja, R. (2012). Metode penelitian kelas untuk meningkatkan kinerja guru dan dosen. Bandung: PT. Remaja Rosda Karya. 